\title{
Effects of overfeeding by gastric intubation on body composition of adult female rats and on heat production during feeding and fasting
}

\author{
BY K. J. MCCRACKEN \\ Agricultural and Food Chemistry Research Division, Department of Agriculture, Northern \\ Ireland and The Queen's University of Belfast, Newforge Lane, Belfast BT9 5PX, \\ Northern Ireland
}

AND MARY A. MCNIVEN*

Department of Animal Husbandry, Swedish University of Agricultural Sciences, Uppsala, Sweden

(Received 24 May 1982 - Accepted 21 October 1982)

1. The effects of overfeeding by gastric intubation on the body composition and energy metabolism of adult female rats were studied in three experiments.

2. In Expt 1 there were significant $(P<0.001)$ linear increases in carcass dry matter, fat and energy during a $10 \mathrm{~d}$ period as metabolizable energy (ME) intake was increased from 160 to $300 \mathrm{~kJ} / \mathrm{d}$.

3. In Expt 2 rats were fed to maintain weight $(130 \mathrm{~kJ} / \mathrm{d})$ or given approximately $270 \mathrm{~kJ} / \mathrm{d}$ for $120 \mathrm{~d}$. Measurements of fed and fasting heat production (FHP) were made at intervals. FHP (kJ/d per kg metabolic weight $\left(\mathrm{W}^{0 \cdot 75}\right)$ ) decreased by $15 \%$ over the $120 \mathrm{~d}$ period on both treatments. The mean carcass weight of the overfed rats increased from 216 to $465 \mathrm{~g}$, over $90 \%$ of the increase being due to fat.

4. In Expt 3 rats were fed to maintain weight $(137 \mathrm{~kJ} / \mathrm{d})$ or given approximately $300 \mathrm{~kJ} / \mathrm{d}$ for $6,12,18,24$ or $30 \mathrm{~d}$. There were significant linear increases $(P<0.001)$ with time in carcass weight, dry matter, fat and energy. FHP, measured before slaughter, increased from 118 to $160 \mathrm{~kJ} / \mathrm{d}$ but remained constant at $334 \mathrm{~kJ} / \mathrm{d}$ per kg W0.75.

5. In all three experiments there were significant $(P<0.01)$ increases in carcass crude protein (nitrogen $\times 6.25)$ in response to overfeeding.

6. The efficiency of utilization of energy for production (Expt 1) or for maintenance and production (Expts 2 and 3) averaged $0.92,0.86,0.88$ respectively.

7. It is concluded that FHP per $\mathrm{kg} \mathrm{W} \mathrm{W}^{0.75}$ may be regarded as constant over a wide range of body compositions in adult rats made obese by gastric intubation, and that energy utilization conforms to classical concepts.

Whereas the energy intake of adult domesticated animals is usually restricted by man in the interests of economic production, the energy consumption of adult man is affected by environmental and social factors. In affluent societies energy consumption frequently exceeds expenditure with the result that body-weight and body fat increase (Garrow, 1978). The relationships between food intake, metabolic rate and energy retention in the human are still not clearly established and conflicting reports on the effects of overfeeding on the energy balance and weight gain of normal adult humans have been published (Passmore et al. 1955; Miller \& Mumford, 1967; Apfelbaum et al. 1971; Sims et al. 1973; Norgan \& Durnin, 1980).

The laboratory rat provides a useful model for studies on overfed adults, since it is possible to induce it to consume excess energy by feeding high-fat diets (Mickelsen et al. 1955), by offering a varied diet (Scalafani \& Springer, 1976) or by gastric intubation (Cohn \& Joseph, 1959). Experimental animals may be kept in controlled environmental conditions for long periods and body composition accurately determined, thus eliminating many of the assumptions which have to be made with homo sapiens.

Experiments with overfed adult rats were begun in our laboratory in 1974 and preliminary

\footnotetext{
* Present address: Department of Animal Nutrition, Agricultural University of Norway, Box 25, 1421 Aas-NLH,
} Norway. 
Table 1. Composition and analysis $(\mathrm{g} / \mathrm{kg}$ dry matter) of the experimental diets

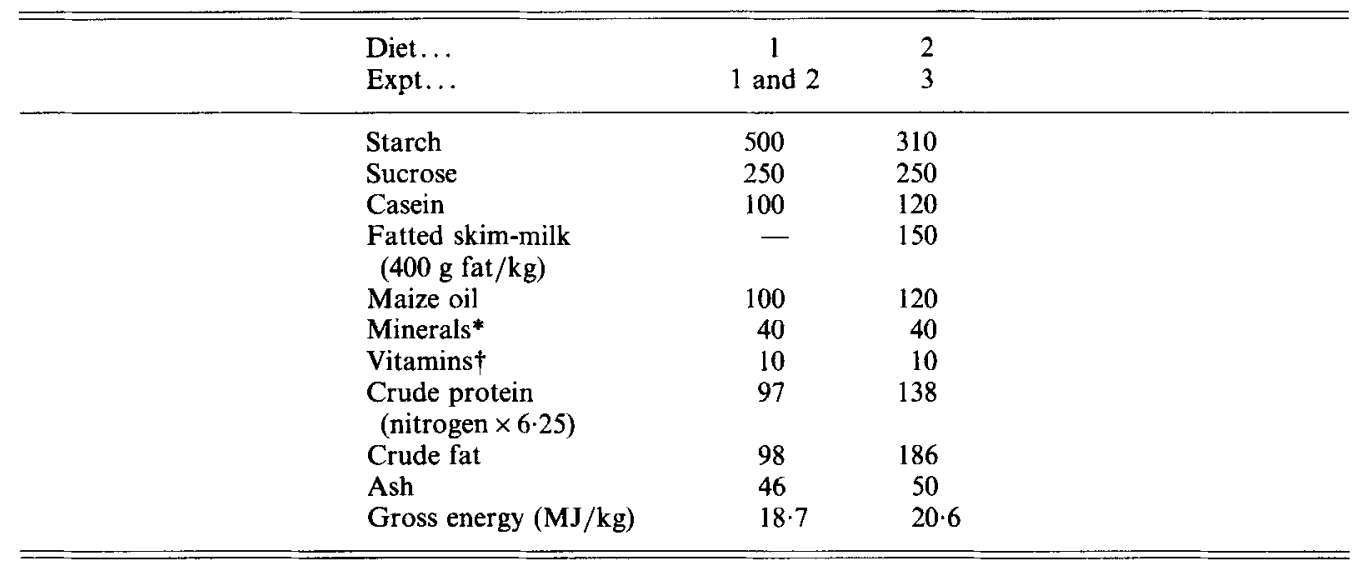

* The mineral mixture supplied $(\mathrm{g} / \mathrm{kg}$ diet): calcium orthophosphate $17 \cdot 4$, potassium chloride $10 \cdot 8$, disodium hydrogen sulphate $4 \cdot 6$, magnesium sulphate $8 \mathrm{mg}$, sodium fluoride $0 \cdot 4 \mathrm{mg}$.

$\dagger$ The vitamin mixture supplied (mg/kg diet): ascorbic acid 200, choline chloride 750, myo-inositol 50, nicotinic acid 20 , riboflavin 5 , pyridoxine hydrochloride 5 , thiamin hydrochloride 5 , calcium pantothenate 15 , folic acid $0 \cdot 5$, biotin $100 \mu \mathrm{g}$, cyanocobalamin $10 \mu \mathrm{g}$.

results have been published (McCracken, 1975, 1976; McCracken \& Gray, 1976; McCracken \& McNiven, 1982). Gastric intubation was chosen as the feeding technique since this method ensures controlled consumption of a balanced diet. The aims of the experiments to be described were (1) to establish the efficiency of utilization of energy for fattening in the overfed adult rat (2) to simulate obesity and examine the changes in body composition (3) to study the relationship between body mass and fasting heat production (FHP). Expt 1 was a short-term experiment to measure the efficiency of energy utilization. In retrospect it was considered that the high efficiency obtained may have been partly due to the environmental temperature being below thermoneutrality (Sørenson, 1962) and subsequent experiments were conducted at $30^{\circ}$. Expt 2 was designed to provide information on long-term changes in body composition and FHP. Expt 3 was intended to overcome some of the problems of interpretation in Expt 2 due to possible carry-over effects of intermittent fasting, and to examine the time-course relationship of protein deposition during overfeeding.

\section{EXPERIMENTAL}

Certain aspects of methodology were common to the three experiments. Adult, female Norway Hooded rats which had been bred in the laboratory were used. In Expts 1 and 2 they were approximately 5 months old and in Expt 3 they were 10 months old at the start of the experiment. This difference in age was not considered to be of importance. The diets used in the three experiments contained similar ingredients, but in Expt 3 the fat content was increased to conform with previous experiments by McNiven (1980) (Table 1). They were mixed to a slurry with warm water immediately before feeding and administered by gastric intubation. Representative samples were taken at each feeding time for dry matter (DM) determinations $\left(100^{\circ}\right.$ in a forced-draught oven for $\left.24 \mathrm{~h}\right)$. The DM content of the slurry was approximately $0.75 \mathrm{~g} / \mathrm{ml}$ in Expts 1 and 2 and $0.85 \mathrm{~g} / \mathrm{ml}$ in Expt 3 .

Rats slaughtered for carcass analysis were immediately eviscerated and undigested food residues removed from the gastrointestinal tract. The carcasses were prepared for analysis 
by autoclaving for $20 \mathrm{~min}$ and then homogenizing with approximately $200 \mathrm{ml}$ water in a Kenwood mixer. The homogenate was freeze-dried and milled. The dried samples were analysed for crude protein (nitrogen $\times 6.25 ; \mathrm{CP}$ ) by the macro-Kjeldahl method, for ash by ignition in a muffle furnace at $450^{\circ}$ for $8 \mathrm{~h}$, and for diethyl ether extract by the Soxhlet method (light petroleum $40-60^{\circ}$ b.p.). Carcass energy was calculated from protein and fat using the factors 23.8 and $39.3 \mathrm{MJ} / \mathrm{kg}$ respectively (Brouwer, 1965). The energy contents of the diets were determined in an adiabatic bomb calorimeter.

\section{Expt 1}

Eighteen rats (mean weight $227 \mathrm{~g}$ ) were fed on diet 1 (Table 1) ad lib. in powder form for $7 \mathrm{~d}$, and subsequently as a slurry, three times daily, by gastric intubation. During the first $3 \mathrm{~d}$ the volume administered was increased $(12,15,18 \mathrm{ml} / \mathrm{d}$ on consecutive days) to facilitate adaptation to the procedure. The rats were then randomly allocated to one of six groups. One group (T1) was slaughtered for initial carcass composition. Groups T2-T6 respectively were given $4,5,6,7$ or $8 \mathrm{ml} /$ feed, three times daily, for $10 \mathrm{~d}$. They were kept singly in wire cages. Room temperature was $24 \pm 1^{\circ}$. Faeces were collected over the $10 \mathrm{~d}$ period for the estimation of digestible energy (DE) intake. Metabolizable energy (ME) was calculated as $0.96 \mathrm{DE}$. At the end of the feeding period all rats were slaughtered, certain organs were removed and weighed and the carcasses analysed. Statistical analysis of the results was based on analysis of variance.

\section{Expt 2}

Eighteen rats (mean weight $220 \mathrm{~g}$ ) were allocated to one of six groups. They were placed in wire cages, three rats per cage, and given diet 1 (Table 1) by gastric intubation. For the first $5 \mathrm{~d}$ all rats were fed twice daily at 09.00 and 17.00 hours and given $5 \mathrm{ml}$ diet $/$ feed, i.e. an intake designed to maintain zero energy balance. Room temperature was $30 \pm 1^{\circ}$. On the 5 th day, fed heat production was measured for $24 \mathrm{~h}$ in a closed-circuit respiration chamber (Waring \& Brown, 1965; Gray \& McCracken, 1976). The rats were fasted overnight and FHP measured during the period $2448 \mathrm{~h}$ after the last feed. Two groups (T5 and T6) were slaughtered for initial carcass composition. One group (T1) was returned to the initial feeding regimen and fed to maintain body-weight. In order to do this, intake was reduced to $9 \mathrm{ml} / \mathrm{d}$ and eventually to $8 \mathrm{ml} / \mathrm{d}$. The other groups (T2-T4) were increased to $10 \mathrm{ml} /$ feed over $5 \mathrm{~d}$. They were maintained on the respective treatments for $120 \mathrm{~d}$. At approximately $20 \mathrm{~d}$ intervals heat production was measured for $24 \mathrm{~h}$ during feeding and then during fasting as described above. At the end of the experiment the rats were slaughtered and the carcasses analysed.

\section{Expt 3}

Forty-two rats (mean weight $260 \mathrm{~g}$ ) were grouped into six weight blocks and allocated to one of seven treatment groups (T1-T7) which were randomized within weight blocks.

The T1 rats were slaughtered for initial carcass composition. The T7 rats were fed to maintain zero energy balance $(8 \mathrm{ml} / \mathrm{d})$. Rats in groups T2-T6 respectively were fed $20 \mathrm{ml} / \mathrm{d}$ in two feeds for $6,12,18,24$ or $30 \mathrm{~d}$. After the appropriate feeding period, the FHP of each rat was measured for $24 \mathrm{~h}$ in a closed-circuit respiration chamber (Waring \& Brown, 1965; $\mathrm{McNiven}, 1980$ ) before slaughter. Room and chamber temperatures were $30 \pm 1^{\circ}$. Since only two chambers were available the rats were started on the experiment over a $3 \mathrm{~d}$ period. On day 1 of the experimental period, each rat received $4 \mathrm{ml} /$ feed at 09.00 and 20.00 hours. T1 rats were placed in the respiration chamber at 09.00 hours on the following day and slaughtered $24 \mathrm{~h}$ later. T2-T6 rats received $6,7,8,9,10 \mathrm{ml}$ per feed on days 2-6 respectively to allow the stomach to become accustomed to the large volume of feed. On day 6, T2 rats received $4 \mathrm{ml}$ at the 20.00 hours feed and were placed in the respiration chamber at 09.00 hours on day 7 . The same procedure was followed with T3-T6 rats. The rats were kept 
Table 2. Expt 1. Final live weight, weights of liver and epididymal fat and total body water (g) of rats killed for initial carcass composition (T1) or tube-fed 12,15,18,21 or $24 \mathrm{ml} / \mathrm{d}$ (T2-T6 respectively) of a synthetic diet $\dagger$ as a slurry for a $10 \mathrm{~d}$ period

(Mean values for three rats, $10 \mathrm{df}$ )

\begin{tabular}{lcccc}
\hline Treatment & $\begin{array}{c}\text { Final } \\
\text { live wt }\end{array}$ & $\begin{array}{c}\text { Liver } \\
\text { wt }\end{array}$ & $\begin{array}{c}\text { Epididymal } \\
\text { fat }\end{array}$ & $\begin{array}{c}\text { Total body } \\
\text { water }\end{array}$ \\
\hline T1 & 227 & 6.4 & 18.4 & 122 \\
T2 & 232 & 6.6 & $17 \cdot 8$ & 124 \\
T3 & 245 & 6.8 & 22.7 & 124 \\
T4 & 254 & 7.4 & 21.6 & 131 \\
T5 & 272 & 7.9 & 26.1 & 134 \\
T6 & 287 & $8 \cdot 4$ & 29.8 & 132 \\
Statistical & $* * *$ & $* * *$ & $* *$ & NS \\
significance & & & & 3.7 \\
SEM & 4.5 & 0.21 & 1.70 & 3.7 \\
\hline
\end{tabular}

NS, not significant; ** $P<0.01, \quad * * * P<0.001$.

$\dagger$ Diet 1 ; for details, see Table 1 .

in pairs during the feeding period to facilitate excreta collection but FHP measurements were made on individual animals. The diet used in this experiment (diet 2, Table 1) was found to produce a slurry, of a suitable consistency for tube-feeding, with a DM content of $0.85 \mathrm{~g} / \mathrm{ml}$. The ME content of the diet was determined on nine pairs of rats during a $7 \mathrm{~d}$ collection period. The faeces and urine were collected together in $50 \mathrm{ml}$ oxalic acid $(25 \mathrm{~g} / 1)$. The excreta were removed daily and held at $-20^{\circ}$ until the end of the collection period, when the mixture was weighed, homogenized and analysed for energy.

Three animals died prematurely as a result of food entering the lungs during feeding. Analysis of variance and linear regression were conducted using an iterative procedure to adjust for missing plots.

\section{RESULTS \\ Expt 1}

There were highly significant linear responses $(P<0.001)$ in live weight and liver weight (Table 2) and in gain of carcass DM, fat and energy (Table 3) to the increasing levels of energy intake. The weight of epididymal fat increased by $66 \%$ from T2 to T6 $(P<0.01)$ and there was a small but significant increase $(P<0.01)$ in carcass $\mathrm{CP}$. Body water was not significantly different between treatments and this was reflected in the significant $(P<0.01)$ difference in the energy content of the carcass gain which ranged from $15.5 \mathrm{MJ} / \mathrm{kg}$ on the low-intake diets (T2) to $30.8 \mathrm{MJ} / \mathrm{kg}$ for the T6 rats.

The linear regression of energy retention (ER) $v$. ME was highly significant and yielded the equation (Fig. 1):

$$
\mathrm{ER}(\mathrm{kJ} / \mathrm{d})=0.915( \pm 0.042) \mathrm{ME}-130.8 \quad(r 0.99)
$$

\section{Expt 2}

There was no significant change in carcass weight as a result of prolonged feeding at low intake (T2) (Table 4). There was a significant reduction in carcass CP $(P<0.01)$ and an increase in mean carcass fat, though this failed to attain statistical significance. Carcass $C P$ increased $(P<0.05)$ by $14 \%$ on the high-intake diet (T3) and there were highly significant 
Table 3. Expt 1. Increases in carcass content of dry matter $(D M)$, crude protein (nitrogen $\times 6 \cdot 25$; $C P)$, fat and energy of rats tube-fed $12,15,18,21$ or $24 \mathrm{ml} / \mathrm{d}(T 2-T 6$ respectively) of a synthetic diet $\dagger$ for a 10 d period

(Mean values for three rats, $8 \mathrm{df}$ )

\begin{tabular}{|c|c|c|c|c|c|}
\hline Treatment & $\begin{array}{l}\text { DM } \\
\text { gain } \\
\text { (g) }\end{array}$ & $\begin{array}{l}C P \\
\text { gain } \\
(g)\end{array}$ & $\begin{array}{l}\text { Fat } \\
\text { gain } \\
(\mathrm{g})\end{array}$ & $\begin{array}{l}\text { Energy } \\
\text { gain } \\
(k J)\end{array}$ & $\begin{array}{c}\text { Energy } \\
\text { content of } \\
\text { carcass gain } \\
(\mathrm{kJ} / \mathrm{g})\end{array}$ \\
\hline $\mathrm{T} 2$ & 4.0 & $1 \cdot 1$ & $2 \cdot 3$ & 116 & 15.5 \\
\hline T3 & 13.9 & $1 \cdot 1$ & $11 \cdot 6$ & 480 & $26 \cdot 5$ \\
\hline $\mathrm{T} 4$ & 19.7 & $1 \cdot 1$ & 17.9 & 721 & $27 \cdot 9$ \\
\hline T5 & 34.4 & $2 \cdot 5$ & 31.4 & 1282 & $28 \cdot 8$ \\
\hline T6 & $47 \cdot 4$ & $2 \cdot 3$ & $43 \cdot 8$ & 1761 & 30.8 \\
\hline $\begin{array}{l}\text { Statistical } \\
\text { significance }\end{array}$ & $* * *$ & $* *$ & $* * *$ & $* * *$ & $* *$ \\
\hline SEM & $1 \cdot 30$ & 0.20 & 1.05 & $41 \cdot 1$ & 2.04 \\
\hline
\end{tabular}

** $P<0.01, * * * P<0.001$.

$\dagger$ Diet 1 ; for details, see Table 1 .

Table 4. Expt 2. Carcass composition of starting controls after $48 \mathrm{~h}$ fast (TI), rats given diet $1 \dagger$ to maintain body-weight for $120 \mathrm{~d}$ with intermittent $48 \mathrm{~h}$ fasting periods $(T 2)$ and those given diet $1+(20 \mathrm{ml} / \mathrm{d})$ to increase body-weight for $120 \mathrm{~d}$ with intermittent $48 \mathrm{~h}$ fasting periods (T3)

(Mean values for six, three and nine rats $\mathrm{T} 1-\mathrm{T} 3$ respectively, $15 \mathrm{df}$ )

\begin{tabular}{|c|c|c|c|c|c|}
\hline Treatment & $\begin{array}{c}\text { Carcass } \\
\text { wt (g) }\end{array}$ & $\begin{array}{l}\text { Carcass } \\
\text { CP (g) }\end{array}$ & $\begin{array}{l}\text { Carcass } \\
\text { fat }(\mathrm{g})\end{array}$ & $\begin{array}{l}\text { Carcass } \\
\text { DM }(\mathrm{g})\end{array}$ & $\begin{array}{c}\text { Carcass } \\
\text { energy }(\mathrm{MJ})\end{array}$ \\
\hline $\mathrm{T} 1$ & 216 & $41 \cdot 9$ & $32 \cdot 9$ & 84.9 & $2 \cdot 3$ \\
\hline $\mathrm{T} 2$ & 211 & $33 \cdot 8$ & $49 \cdot 4$ & 90.7 & $2 \cdot 7$ \\
\hline T3 & 465 & $48 \cdot 2$ & $264 \cdot 2$ & $321 \cdot 8$ & $11 \cdot 5$ \\
\hline $\begin{array}{l}\text { Statistical } \\
\text { significance }\end{array}$ & $* * *$ & $* * *$ & $* * *$ & $* * *$ & $* * *$ \\
\hline $\begin{array}{l}\text { SE of a difference } \\
\text { T1 v. T2 }\end{array}$ & $8 \cdot 7$ & $2 \cdot 13$ & $10 \cdot 87$ & $10 \cdot 78$ & 0.41 \\
\hline
\end{tabular}

$\mathrm{CP}$, crude protein (nitrogen $\times 6.25)$; DM, dry matter.

**** $P<0.001$.

$\uparrow$ For details, see Table 1.

$(P<0.001)$ increases in carcass DM, fat and energy. The FHP $(\mathrm{kJ} / \mathrm{kg}$ metabolic weight $\left(\mathrm{W}^{0 \cdot 75}\right)$ ) of all four groups declined by approximately $15 \%$ over the $120 \mathrm{~d}$ period but there was no significant difference between the low- and high-intake groups (Fig. 2). The mean ME intake, energy retention, FHP and calculated efficiency of energy utilization for maintenance and production $(k)$ of the three $\mathrm{T} 3$ groups on seven occasions during the experiment are shown in Table 5. FHP increased from 100 to $161 \mathrm{~kJ} /$ rat per $\mathrm{d}$ and a corresponding decline in energy retention during overfeeding from 124 to $67 \mathrm{~kJ} / \mathrm{rat}$ per d yielded a mean value for $k$ of $0 \cdot 87$. 


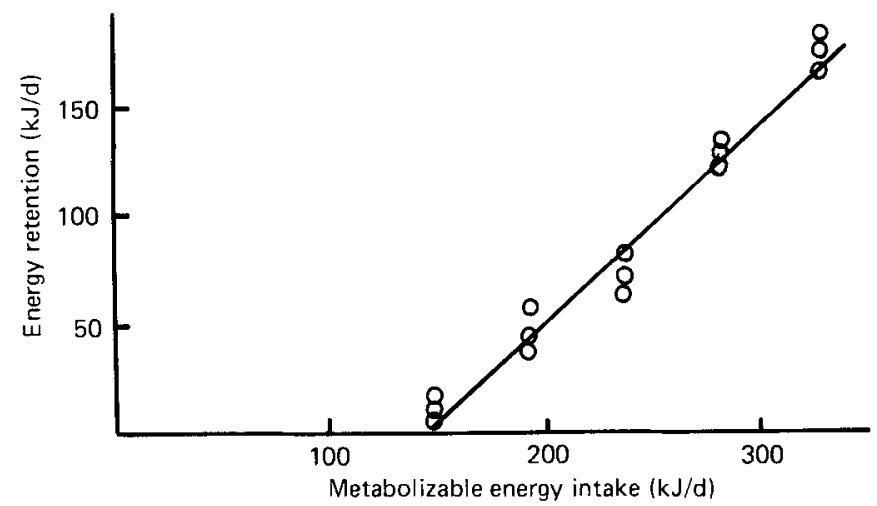

Fig. 1. Expt 1. Energy retention (kJ/d; ER) v. metabolizable energy intake (MJ ; ME) of adult rats given diet 1 (Table 1 ) by gastric intubation for $10 \mathrm{~d}$ (Expt 1$)$.

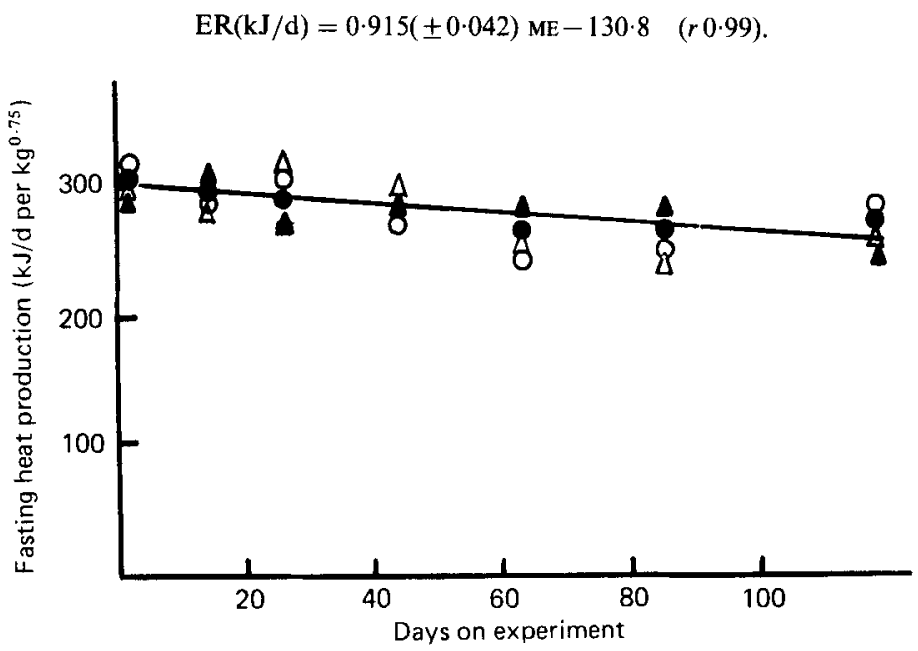

Fig. 2. Expt 2. Fasting heat production (kJ/d per kg body-weight ( $\left.\mathbf{W}^{0.75}\right)$; FHP) of adult rats given diet 1 (see Table 1) to maintain constant body-weight $(\Delta)$ or to increase body-weight $(O, O, \triangle)$ for $120 \mathrm{~d}$ with intermittent $48 \mathrm{~h}$ fasting periods (Expt 2).

$$
\text { FHP(kJ/d per kg body-weight } \left.{ }^{0.75}\right)=305-0.40( \pm 0.087) \mathrm{D} \quad(r 0.67),
$$

where $\mathrm{D}$ is days overfeeding.

Table 5. Expt 2. Energy utilization ( $k J /$ rat per $d$ ) of force-fed rats as determined by indirect calorimetry on seven occasions during a 120 d experiment

(Mean values with their standard errors for three groups with three rats/group)

\begin{tabular}{|c|c|c|c|c|c|c|c|c|c|}
\hline \multirow{2}{*}{$\begin{array}{c}\text { Day of } \\
\text { experiment }\end{array}$} & \multirow{2}{*}{$\begin{array}{c}\mathrm{ME} \\
\text { intake }\end{array}$} & \multicolumn{2}{|c|}{ ER } & \multicolumn{2}{|c|}{ FHP } & \multicolumn{2}{|c|}{ Net energy } & \multicolumn{2}{|c|}{$k$} \\
\hline & & Mean & SEM & Mean & SEM & Mean & SEM & Mean & SEM \\
\hline 0 & $157 \cdot 4$ & $38 \cdot 4$ & $2 \cdot 13$ & $100 \cdot 3$ & 1.62 & $138 \cdot 7$ & 1.73 & 0.88 & 0.010 \\
\hline 9 & $269 \cdot 9$ & $123 \cdot 6$ & $2 \cdot 01$ & $104 \cdot 3$ & $0 \cdot 31$ & $227 \cdot 9$ & $2 \cdot 12$ & 0.84 & $0 \cdot 012$ \\
\hline 24 & $284 \cdot 0$ & $125 \cdot 8$ & $3 \cdot 32$ & $118 \cdot 1$ & $2 \cdot 58$ & $243 \cdot 9$ & 1.99 & 0.86 & $0 \cdot 006$ \\
\hline 42 & $266 \cdot 2$ & $106 \cdot 0$ & $2 \cdot 45$ & $122 \cdot 6$ & $1 \cdot 22$ & $228 \cdot 6$ & 1.87 & 0.86 & $0 \cdot 010$ \\
\hline 62 & $268 \cdot 0$ & $111 \cdot 5$ & $2 \cdot 72$ & $118 \cdot 5$ & $1 \cdot 36$ & $230 \cdot 0$ & 1.58 & 0.86 & 0.006 \\
\hline 84 & $267 \cdot 0$ & $101 \cdot 2$ & $4 \cdot 15$ & $130 \cdot 0$ & $2 \cdot 83$ & $231 \cdot 2$ & $5 \cdot 61$ & 0.87 & 0.019 \\
\hline 117 & $270 \cdot 3$ & $67 \cdot 4$ & $3 \cdot 21$ & $161 \cdot 3$ & 0.59 & 228.7 & $1 \cdot 31$ & 0.85 & 0.007 \\
\hline
\end{tabular}

ME, metabolizable energy; ER, energy retention; FHP, fasting heat production; $k$, calculated efficiency for maintenance and production. 
Table 6. Expt 3. Carcass composition $(\mathrm{g})$ and energy retention $(\mathrm{MJ} ; \mathrm{ER})$ of rats force-fed for $0,6,12,18,24$ or $30 d$ (T1-T6 respectively) $20 \mathrm{ml}$ diet $2 / d$ (Table l) or given $8 \mathrm{ml} / \mathrm{d}$ for $54 d(T 7)$

(Mean values for five or six rats, 28 or $22 \mathrm{df}$ )

\begin{tabular}{|c|c|c|c|c|c|c|c|c|}
\hline \multirow[b]{2}{*}{ Treatment } & \multirow{2}{*}{$\begin{array}{l}\text { No. } \\
\text { of rats }\end{array}$} & \multicolumn{5}{|c|}{ Carcass analyses } & \multirow{2}{*}{$\begin{array}{c}\text { Energy } \\
\text { content } \\
\text { of gain } \\
(\mathrm{MJ} / \mathrm{kg})\end{array}$} & \multirow{2}{*}{$\begin{array}{l}E R \dagger \\
(M J)\end{array}$} \\
\hline & & Wt $(\mathrm{g})$ & DM (g) & $\mathrm{CP}(\mathrm{g})$ & Fat $(g)$ & Energy (MJ) & & \\
\hline $\mathrm{T} 1$ & 6 & 244 & 107.0 & $44 \cdot 6$ & 53.7 & $3 \cdot 20$ & - & - \\
\hline $\mathrm{T} 2$ & 6 & 263 & $116 \cdot 0$ & 45.6 & $60 \cdot 2$ & 3.49 & 18.4 & 0.31 \\
\hline T3 & 6 & 285 & 140.4 & $45 \cdot 6$ & 85.8 & $4 \cdot 50$ & $29 \cdot 4$ & $1 \cdot 32$ \\
\hline T4 & 5 & 311 & 162.0 & $48 \cdot 5$ & 106.7 & $5 \cdot 41$ & 31.0 & $2 \cdot 26$ \\
\hline T5 & 5 & 338 & $194 \cdot 0$ & $48 \cdot 1$ & $136 \cdot 2$ & 6.57 & 33.9 & 3.35 \\
\hline T6 & 5 & 365 & $218 \cdot 1$ & $48 \cdot 5$ & $162 \cdot 0$ & $7 \cdot 54$ & $35 \cdot 3$ & $4 \cdot 25$ \\
\hline $\mathrm{T} 7$ & 6 & 257 & 117.5 & $44 \cdot 9$ & $63 \cdot 2$ & 3.59 & $30 \cdot 7$ & 0.37 \\
\hline $\begin{array}{l}\text { Statistical } \\
\text { significance }\end{array}$ & & $* * *$ & $* * *$ & $* *$ & $* * *$ & $* * *$ & $* *$ & $* * *$ \\
\hline SEM $(n 5)$ & & $3 \cdot 3$ & $4 \cdot 1$ & 0.86 & $4 \cdot 60$ & 0.173 & $3 \cdot 19$ & 0.179 \\
\hline
\end{tabular}

DM, dry matter; CP, crude protein (nitrogen $\times 6 \cdot 25$ ).

** $P<0.01$, *** $P<0.001$.

$\dagger$ See below for ME intakes.

\section{Expt 3}

The ME: gross energy (GE) value for diet 2 was $0.925 \pm 0.004$ and the ME content of the diet was $19 \cdot 1 \mathrm{MJ} / \mathrm{kg} \mathrm{DM}$. The mean ME intakes for T2-T6 rats respectively were $1 \cdot 26,3 \cdot 24,5 \cdot 29$, $7 \cdot 28,9 \cdot 18 \mathrm{MJ}$.

There were highly significant $(P<0.001)$ linear increases in carcass weight, DM, fat and energy with increasing period of time on the high-energy intake (Table 6). Carcass CP increased $(P<0.01)$ by $10 \%$ between $\mathrm{T} 1$ and T6 rats, the linear component being highly significant. Approximately $10 \%$ of the CP increase was in the liver. The mean carcass weight of the rats which were fed to maintain constant body-weight (T7 rats) increased slightly over the $42 \mathrm{~d}$ feeding period and this was associated with increases in carcass DM, fat and energy but not carcass CP or body water. The energy content of the gain was lowest in T2 rats, corresponding to the period when the daily energy intake was being increased, and highest in the T6 rats $(P<0.01)$ where $90 \%$ of the carcass gain was fat.

The FHP (Table 7) increased from $118 \mathrm{~kJ} / \mathrm{d}$ in group $\mathrm{T} 1$ to $160 \mathrm{~kJ} / \mathrm{d}$ in group T6 $(P<0.001)$. A regression equation of the form, FHP $=a \mathrm{~W}^{b}$ yielded the equation:

$$
\mathrm{FHP}=317( \pm 23.9) \mathrm{kJ} / \mathrm{d} \text { per } \mathrm{kg} \mathrm{W} \mathrm{W}^{0.72} \quad(r 0.871) \text {. }
$$

However, when the value 0.75 was inserted for $b$, the mean value for $a$ was $334 \mathrm{~kJ} / \mathrm{d}$ and there were no significant treatment effects.

Using the mean value for FHP and the energy retention values in Table 6 , the calculated values of $k$ for T2-T6 rats respectively were $0 \cdot 86,0.86,0.87,0.90,0.91$ (SEM 0.013).

\section{DISCUSSION}

Despite the fact that the animals used in all three experiments had attained stable adult weight before the period of force-feeding, rapid and prolonged weight gains occurred as a result of the high-energy intakes achieved by tube-feeding. In Expt 1 the rats given $24 \mathrm{ml} / \mathrm{d}$ (approximately $18 \mathrm{~g} \mathrm{DM} / \mathrm{d}$ ) gained $6 \mathrm{~g} / \mathrm{d}$ containing $4.7 \mathrm{~g}$ DM of which over $90 \%$ was fat. Although there were differences in environmental temperature, age, feeding levels employed 
Table 7. Expt 3. Fasting heat production (FHP) of adult rats force-fed for 0, 6, 12, 18,24 or $30 \mathrm{~d}$ (treatments $\mathrm{T} 1-\mathrm{T} 6$ respectively) $20 \mathrm{ml}$ diet $2 / \mathrm{d}$ (Table $\mathrm{l}$ )

(Mean values for five or six rats, $21 \mathrm{df}$ )

\begin{tabular}{lcccccccc}
\hline \hline Treatment... & T1 & T2 & T3 & T4 & T5 & T6 & $\begin{array}{c}\text { Statistical } \\
\text { significance }\end{array}$ & $\begin{array}{c}\text { SEM } \\
(n \text { 5) }\end{array}$ \\
\hline FHP $(\mathrm{kJ} / \mathrm{d})$ & 118 & 125 & 132 & 139 & 147 & 160 & $* * *$ & 3.5 \\
FHP $\left(\mathrm{kJ} / \mathrm{d}\right.$ per kg body-wt $\left.{ }^{0.75}\right)$ & 336 & 337 & 333 & 330 & 329 & 338 & NS & 8.9 \\
\hline
\end{tabular}

NS, not significant; $* * * P<0.001$.

and length of experimental period in the three experiments, the trends in body gain and composition were consistent. The energy content of the gain was considerably higher than that found by McNiven (1980) in rats voluntarily consuming a small excess of energy above maintenance and gaining weight much more slowly than in the present experiments. It is not possible to evaluate whether this difference is due to the level of food intake, the method of feeding or the strain of rat. The major implication for studies on adult humans is that energy gain or loss inay be poorly correlated with changes in body-weight. This conclusion is supported by the studies of Passmore et al. (1963), Cohn \& Joseph (1968) and Drenick et al. (1968).

Of particular interest are the changes in carcass composition of the rats in Expt 2 which were fed to maintain body-weight but intermittently fasted for the determination of FHP. Although carcass weight was slightly reduced at the end of the experiment there was a $50 \%$ increase in carcass fat and complementary decreases in carcass CP and water. The loss of protein, corresponding to approximately $1 \mathrm{~g} /$ fasting period, suggests that the rats were unable to make good the deficit between fasting periods. Whilst the situation is not precisely the same as that caused by crash dieting programmes it indicates that the end-product of such a programme could easily be an increase rather than a decrease in body fat even if subsequent food intake were controlled.

During overfeeding there were small but consistent increases in carcass CP. In Expt 1 these were significantly related to energy intake and in Expt 3 there was a linear increase during the $30 \mathrm{~d}$ period. Approximately $10 \%$ of the increase was in the liver. Estimates of the $\mathrm{N}$ content of adipose tissue (K. J. McCracken, unpublished results) suggest that $20-40 \%$ of the increased CP could be associated with the adipose tissue. This indicates that at least half the increase may be associated with the muscle. Further work is required to elucidate the sites and nature of the $\mathrm{N}$ retained during overfeeding.

The efficiency of utilization of energy for production (Expt 1) or for maintenance and production (Expts 2 and 3) was consistently high and indicated that a considerable amount of the fat retention may have arisen from the direct incorporation of absorbed fatty acids rather than from de novo synthesis. The values are similar to those calculated from the results of short-term calorimetric studies on adult humans (Dauncey, 1980; Zed \& James, 1982), though the dietary fat contents were lower than those normally consumed by humans. The highest efficiency was recorded in Expt 1 and this is consistent with the view that part of the heat increment arising from the extra energy ingested would be used to offset the extra-thermoregulatory heat production below the zone of thermoneutrality (Sørenson, 1962).

The levels of energy intake achieved in these experiments (in some instances up to 2.5 times the maintenance energy requirement) are the highest known to the authors in overfeeding studies on adult rats. Despite this, and the length of the experimental period 
Table 8. Expt 3. Percentage increases over the initial values in metabolic body-weight $\left(W^{0 \cdot 75}\right)$ lean body mass (total weight-fat) and fasting heat production $(F H P)$ of rats overfed for 6 , $12,18,24$ or $30 d(T 2-T 6$ respectively)

\begin{tabular}{ccccr}
\hline \hline Treatment & $\begin{array}{c}\text { W0.75 } \\
(\mathrm{kg})\end{array}$ & $\begin{array}{c}\text { Lean body } \\
\text { mass }\end{array}$ & FHP \\
\hline T2 & 4.6 & 5.9 & $4 \cdot 7$ \\
T3 & 12.4 & $4 \cdot 7$ & $11 \cdot 8$ \\
T4 & $21 \cdot 1$ & $7 \cdot 9$ & 17.5 \\
T5 & 28.8 & 6.6 & 24.3 \\
T6 & 36.4 & 6.7 & 35.9 \\
\hline \hline
\end{tabular}

in Expt 2, there was no reduction in efficiency of energy utilization. This is compatible with the classical view of energy metabolism and contrary to the theories of 'luxuskonsumption' or 'diet-induced thermogenesis'. Although one must be cautious in extrapolating from rats to humans it is the opinion of the authors that the rat model described in this paper in terms of stage of maturity, pattern of feeding, environmental temperature and accuracy of measurement of food intake, is more appropriate to the human than studies on young growing rats kept at relatively low environmental temperatures.

The measurements of energy expenditure by indirect calorimetry in Expts 2 and 3 are in good agreement with the carcass values. The mean ME intake of the overfed rats during the $120 \mathrm{~d}$ period in Expt 2 was $27.0 \mathrm{MJ} / \mathrm{rat}$. The mean daily FHP was $122 \mathrm{~kJ}$ corresponding to $14.65 \mathrm{MJ}$ over the complete period. Applying the mean $k$ value (Table 5) the expected ER is $8.9 \mathrm{MJ}$, whereas at slaughter the value was $9.3 \mathrm{MJ}$. The total ME intake of the maintenance group was $12.9 \mathrm{MJ} / \mathrm{rat}$ of which only $0.4 \mathrm{MJ}$ was retained. Correcting for the fasting periods the calculated maintenance requirement was $105.3 \mathrm{~kJ} / \mathrm{d}$ compared with the mean value of $91 \mathrm{~kJ} / \mathrm{d}$ for FHP measured in the respiration chamber.

In Expt 3 the mean ME intake of the maintenance group was $137 \mathrm{~kJ} / \mathrm{d}$. Correcting for ER the maintenance requirement was $129 \mathrm{~kJ} / \mathrm{d}$ or $354 \mathrm{~kJ} / \mathrm{kg} \mathrm{W}^{0.75}$ compared with the mean value for FHP of $334 \mathrm{~kJ} / \mathrm{kg} \mathrm{W}^{0.75}$, determined in the respiration chamber. This represents an efficiency of utilization for maintenance of 0.94 , and indicates good agreement between energy expenditure measured by indirect calorimetry and by the slaughter technique.

One of the main objectives of the study was to establish whether the relationship between FHP and $\mathrm{W}^{0 \cdot 75}$ would alter as a consequence of overfeeding and the resultant changes in body composition. Interpretation of the results of Expt 2 was complicated by the lack of replication and by the losses of body protein which occurred as a consequence of the successive fasts. Expt 3 was designed to overcome this difficulty but was consequently subject to the problems of animal variation. However, the results of these two experiments confirm that, over a wide range of body-weight and body composition, FHP of the adult rat may be regarded as proportional to the $\mathrm{W}^{\mathbf{0} 75}$ irrespective of the previous plane of nutrition. This statement is in agreement with the results of McCracken \& Gray (1976) and Deb et al. (1976) with rats and Blaxter (1976) with sheep.

In contrast, there was no apparent relationship between the increased FHP and lean body mass (Table 8). This is in conflict with the results of Chesters (1975) and Pullar \& Webster (1977). The difference may be due to the age of the rats or to the use of normal rather than genetically-obese animals. In either instance it would be a mistake to attempt to imply any deep physiological significance to the results since the whole body metabolism is the integration of a wide variety of metabolic rates in different tissues. However, the present results are compatible with the view that white adipose tissue is highly active and contributes 
significantly to the maintenance requirement. The conclusion also has practical significance to overfeeding experiments with adult humans in that it provides a basis for calculating the maintenance requirement under standard conditions.

\section{REFERENCES}

Apfelbaum, M., Bostsarron, J. \& Lacatis, D. (1971). Am. J. clin. Nutr. 24, 1405.

Blaxter, K. L. (1976). Publs Eur. Ass. Anim. Prod. no. 19. p. 129.

Brouwer, E. (1965). Publs Eur. Ass. Anim. Prod. no. 11, p. 441.

Chesters, J. K. (1975). Proc. Nutr. Soc. 34, 104A.

Cohn, C. \& Ioseph, D. (1959). Am. J. Physiol. 196, 965.

Cohn, C. \& Joseph, D. (1968). J. Nutr. 96, 94.

Dauncey, M. J. (1980). Br. J. Nutr. 43, 257.

Deb, S., Martin, R. J. \& Hershberger, T. V. (1976). J. Nutr. 106, 191.

Drenick, E. J., Hunt, I. F. \& Swenseid, M. E. (1968). Am. J. Publ. Hlth 58, 477.

Garrow, J. S. (1978). Energy Balance and Obesity in Man. Amsterdam: Elsevier/North-Holland Biomedical Press.

Gray, R. \& McCracken, K. J. (1976). Publs Eur. Ass. Anim. Prod. no. 19, p. 335.

McCracken, K. J. (1975). Proc. Nutr. Soc. 34, 15A.

McCracken, K. J. (1976). Proc. Nutr. Soc. 35, 3A.

McCracken, K. J. \& Gray, R. (1976). Publs Eur. Ass. Anim. Prod. no. 19, p. 141.

McCracken, K. J. \& McNiven, M. A. (1982). Proc. Nutr. Soc. 41, 31 A.

McNiven, M. A. (1980). The effect of body fatness on the maintenance energy requirements of adult rats. PhD Thesis, Sveriges Lantbruksuniversitet, Uppsala, Sweden.

Mickelsen, O., Takahashi, S. \& Craig, C. (1955). J. Nutr. 57, 541.

Miller, D. S. \& Mumford, P. (1967). Am. J. clin. Nutr. 20, 1212.

Norgan, N. G. \& Durnin, J. V. G. A. (1980). Am. J. clin. Nutr. 33, 978.

Passmore, R., Meiklejohn, A. P., Dewar, A. D. \& Thow, R. (1955). Br. J. Nutr. 9, 20.

Passmore, R., Strong, J. A., Swindells, Y. E. \& el Din, N. (1963). Br. J. Nutr. 17, 373.

Pullar, J. D. \& Webster, A. J. F. (1977), Br. J. Nutr. 37, 355.

Scalafani, A. \& Springer, D. (1976). Physiol. Behav. 17, 461.

Sims, E. A. H., Danforth, E., Horton, E. S., Bray, G. A., Glennon, J. A. \& Salans, L. B. (1973). Rec. Progr. Horm. Res. 29, 457.

Sørenson, P. H. (1962). In Nutrition of Pigs and Poultry. Proceedings of the University of Nottingham, 8th Easter School, p. 88 [J. T. Morgan and D. Lewis, editors]. London: Butterworths.

Waring, J. J. \& Brown, W. O. (1965). J, agric. Sci., Camb. 65, 139.

Zed, C. A. \& James, W. P. T. (1982). Proc. Nutr. Soc. 41, 32A. 